\title{
Development of the Coke Oven Industry.
}

\author{
by A. Dierschke
}

(H. Koppers G. m. b. H., Tokyo Office)

-Lecture held at the 16 assembly of coke oven technicians of the Fuel Society of

Japan on Aug. 12, 1955.-

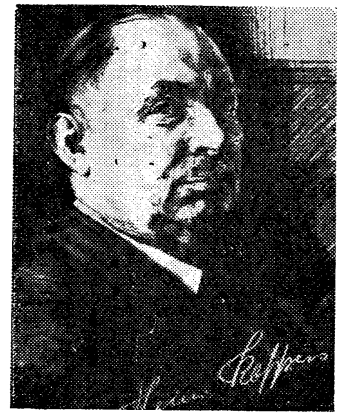

First I beg to express my thanks to the Fuel Society for the kind invitation to speak here to the honorable 'assembly.

I joined the Heinrich Koppers G. m. b. H., Essen in 1912 and remained with Koppers until now, spending 43 years of my life in this firm, and participated in the development of the coke oven and gas industry. 8-1/2 years of that time I have been in Japan in the service of Koppers.

1953:- Dr. Schmalenbach, the expert of Koppers in by-products recovery and treatment, held here at the Fuel Society of Japan a lecture regarding new development of by-product plants. Anything new is not to be reported since that time.

The Koppers combination circulation coke oven system will be known, as it has often been described in the literature. Fundamental news can not be reported, and its development seems to be generally finished. Innovations are restricted to improvements of single parts, as to mechanize the operation, to improve the safety of operations, to adapt the carbonization to special coals, and to meet the increasing demand on coke oven gas supply.

A retrospect of the share of Koppers in the development of the coke oven ndustry may be of interest and shall be given herewith.

Since begining of this century, the development of the coke oven indistry has taken great strides.

To a great part of this development, the coke oven industry is indepted to the late

Dr. Heinrich Koppers and his staff. Dr. Heinrich Koppers was born in 1872, established the
Heinrich Koppers G. m. b. H., Essen, Germany in 1901 , being 29 years of age, and died on September 1941, by a throb of the heart, being 69 years of age.

In 1881, Gustav Hofmann invented the first regeneraitive coke oven with tunnel regenerators running along the battery. This oven was built by several coke oven firms, also by Koppers. However, it was not successful !because it did not permit an equal distribution of the preheated air all over the heating flues of the walls. Mostly waste heat ovens were built at that time, and they were heated by about $80 \%$ of or more of their own produced gas and only max. $20 \%$ could be supplied for other purposes. The waste heat was used for steam recovery. Coke ovens were considered to produce coke only whilst gas and by-products were neglected.

Fig 1. Koksofen mit Längs-bzw Querregeneratoren

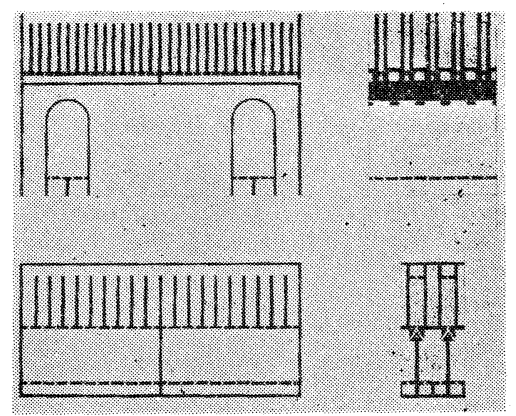

Presuming the future gas demand, Koppers created in 1904 the coke oven with cross regenerators which were directly in connection with the heating flues of the walls over them, and attained with these ovens already a surplus of $50 \%$ of the produced gas.

At that time, Koppers wrote in the patent application: (translated) "The before mentioned coke oven system will be able to satisfy a long 
time desire of better utilization of the fuels in the coal for smokeless combustion of gas, for lighting, for power and heating purposes" The oven system was a great success, inducing many companies to order these ovens and established the quick ascent of Koppers to one of the first engineering company in the coke oven industry. At present throughout the world, all coke oven builders use cross regenerators.

A patent of Koppers on twin flue coke ovens granted in 1906 was not used at that time but 20 years later with the circulation type coke oven.

1904. :- Koppers created also the so called "half direct" process for recovery of tar and ammonia from coke oven gas. Also this process was a great success, and already in 1923 about $90 \%$ of all coke oven plants in the Ruhr-district used this process. Even until today this process could basically not be replaced by a better one. Of course improvements were made meanwhile.

The often made attempts to combine the sulphur in the gas directly with ammonia hava not been successful.

1907 :- Koppers introduced successfully his by-product coke ovens in America, and established there the Koppers Co. Inc., In 1918, already 4996 coke ovens being 91\% of the total were built of the Koppers type in America.

Koppers created there also the first specification for manufacture of silica bricks for coke ovens. The advantages of the [silica bricks are known and they enabled to build the high duty coke ovens of today. Until that time generally chamotte or semi-silica bricks were used. In

\section{Fig 2. Drehrostgenerator Bauart Koppers}

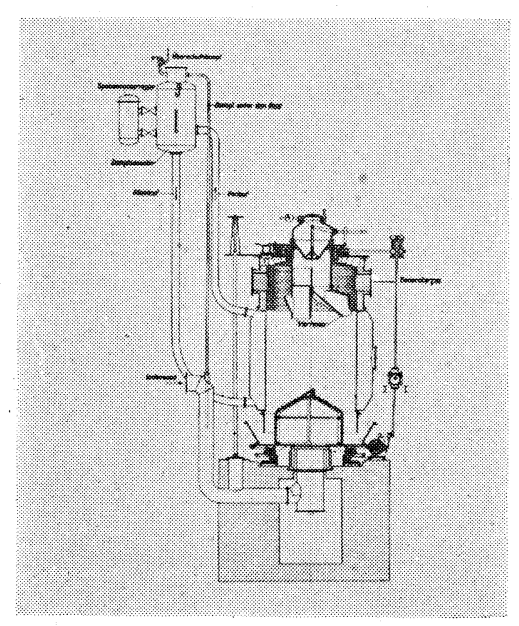

Germany silica bricks were generally used only from 1920 on.

1909 :- Koppers created the first regenerative coke oven, which could be heated by lean gas (producer gas) for the Vienna Gas Works, enabling to supply the total produced coke oven gas as town gas.

Also the first gas producers for gasifying of small coke have been built there for recovery of the heating gas for the coke ovens.

Since that time 430 gas producers have been erected by Koppers, 50 of them in Japan.

A few years ago the capacity per sq. $m$. of shaft diameter could be increased to nearly the double.

Fig 3. Regeneratorgrundri $\beta$ des KoppersVerbund-Kreisstromofen

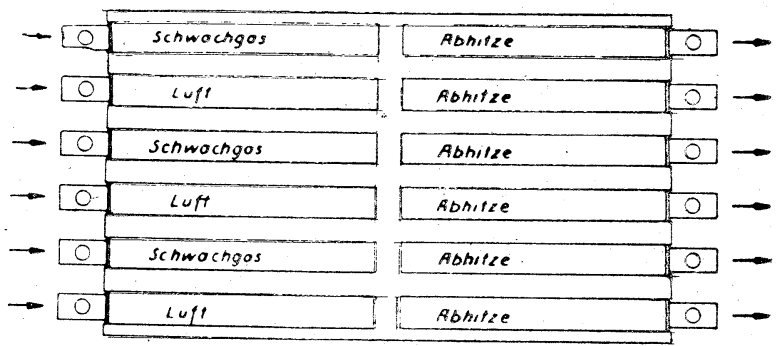

1910 :- Koppers created the first combination type coke ovens, which could be heated selectively either by coke oven gas or lean gas of $900-1100 \mathrm{Kcal} / \mathrm{m}^{3}$.

This oven system intended first for steel works is now used generally as it is able to supply the coke oven gas for other puropses and enables to accommodate the gas supply to the demand.

1910 and 1912 :- Koppers received the first orders from Japan on waste heat and regenerative coke ovens with by-product recovery plants from Messrs. Mitsui Miike Senryō K. K., Tokyo Gas Co. and Nihon Seitetsu K. K., Yawata, in total 263 ovens.

1912 :- the first horizontal narrow chamber ovens have been built for a gas work in Berlin. These ovens had a greater capacity on smaller building space.

1916 :- Koppers introduced the mechanical coke quenching-, screwing-, and loading-plant in Germany.

1920 :- Koppers built his first vertical chamber oven at a small gas work in Silesia. These ovens were successfully introduced in gas works and synthesis works. 
Fig 4. Kippbarer Löschwagen Mitkoksrampe

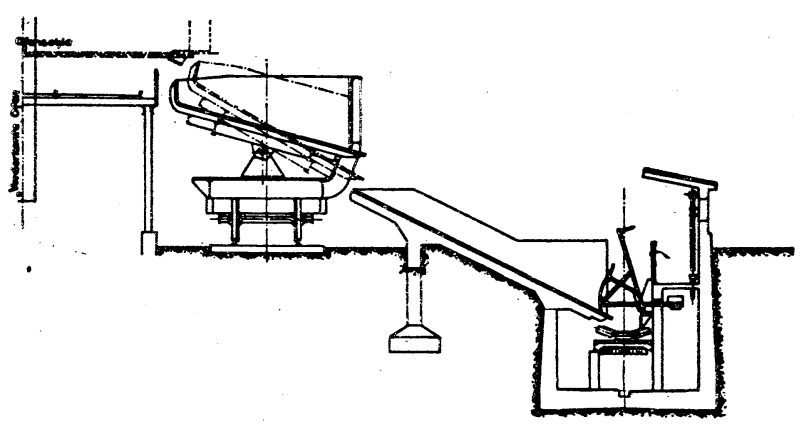

Fig 5. Koksofenbatterie mit Kohlen-und Koksaufbereitung
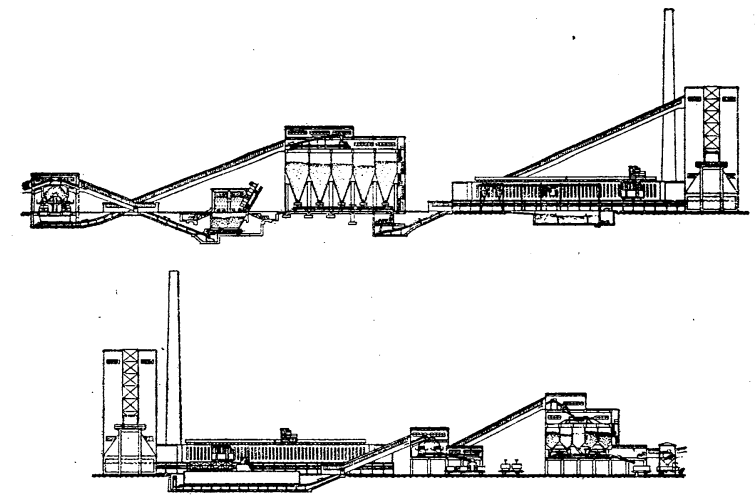

Fig 6. Stetig betriebener Vertikalkammerofen Bauart Koppers

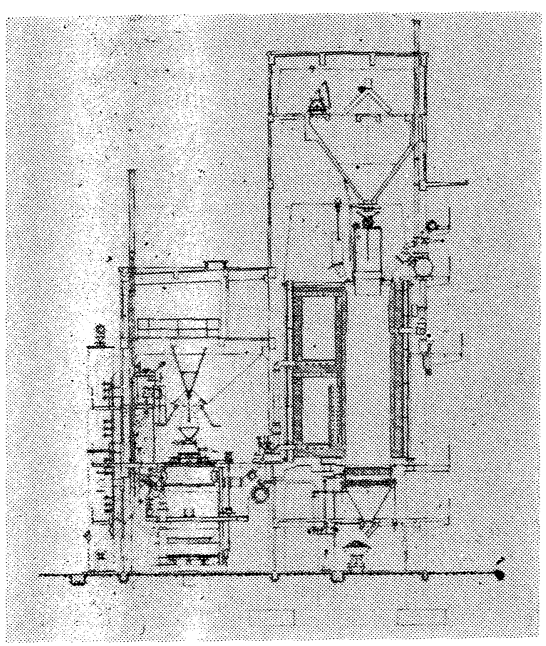

Messrs. Ube Chissc Kogyo K. K. ordered from 1933 to 1940 successively in total 140 ovens of this kind for recovery of ammonia synthesis gas, and these oven are to a part even today in operation.
20 gas producers also ordered by Messrs. Ube produces to a part the heating gas, and to the other part also synthesis gas with oxygen enriched air from coke.

1920 :- Koppers built in Silesia the first narrow chamber coke oven battery with chambers of $350 \mathrm{~mm}$ width. With these ovens Koppers demonstrated that a good coke could be produced with top charge from a weakly caking coal. Until that time for this coal only stamped charge operation gave a reasonable coke. Moreover, the through-put of narrow chambers is greater than that of larger width of chambers.

1925 :- Koppers built his own work for manufacture of high class silica bricks, sillimanite products, magnisiteand chrom ore bricks in DusseldorfHeerdt.

Fig 7. Anordnung der Gas-und Luftführung an der Heizzugsohle des KoppersVerbund-Kreisstromofen.
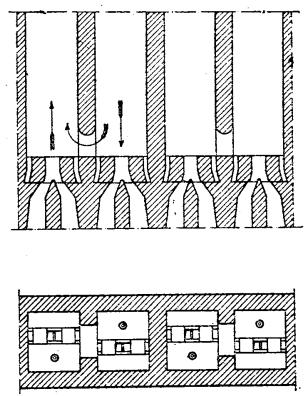

1926 :- the first circulation type regenerative coke ovens have been built and tested. It was found that the circulation principle worked surprisingly well. Specially built testing itwin flues proved that the flues even to $6.0 \mathrm{~m}$ height could be equally heated all over their height with a gas of high calorific value which without circulation stream gives short and hot flames.

1929:- the first battery of circulation combination coke ovens have been built at the Neumühl (Rhld) coke oven plant, after the combination between the half devided regenerator chambers and the twin flues in the oven walls, the fundamental design for the combination circulation type coke oven was created.

Since that time until 1954, more than 4,500 ovens of this kind have been erected by Koppers besides 850 ovens of the regenerative circulation. 
Fig 8. Der Koppers-KreisstromVerbundkoksofen

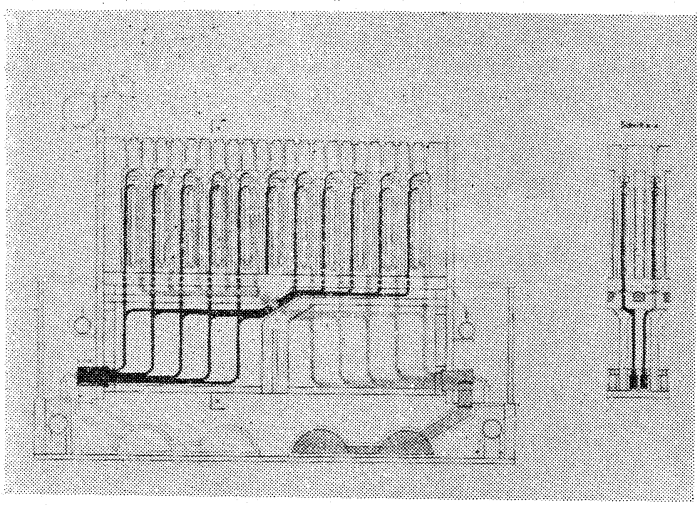

type.

The ovens have never been surpassed in efficiency and easy handling by any other oven system, and the ovens with-stood due to their stability very good the stresses during and short time after the war.

As the heat consumption depends on the size of the chambers, on the quality of the coal, and on the calorific value of the heating gas, and on the water and ash content, it is useless to give general figures. In Koppers Handbuch you will find figures from 504 up to $551 \mathrm{kcal}$ per $\mathrm{kg}$ of moist coal.

A special advantage of the circulation system is its automatic self adjustment to the quality of the gas and to changes in capacity. With high c. v. gas and at low capacity the circulation stream increases, and with lean gas and high capacity the stream decreases. The changing over from one to the otherkind of gas and in capacity is very easy, and the latter can be effected by adjusting of the gas pressure in the supply main and of the chimney draught.

1930 :-a plant of the above ovens has been built in France for medium temperature carbonization of a mixture of high volatile coal with half coke to produce "Carbolux" a very lump size medium temperature coke for vehicle producers. For this process a coke oven which could be very equally heated was required, and the circulation type coke oven fulfilled this condition. The plant was, therefore, several times enlarged.

1930:-Koppers introduced the Thylox-process of the Koppers Co. U. S. A. for desulphurization of gas in Germany, and remodeled it for use of ammonia instead of soda. 9 Thylox plant have been also built in Japan.

1934 :- Koppers improved the circulation type oven by the differential heating device, by
Fig 9. Schema Des Thylox-Verfahrens

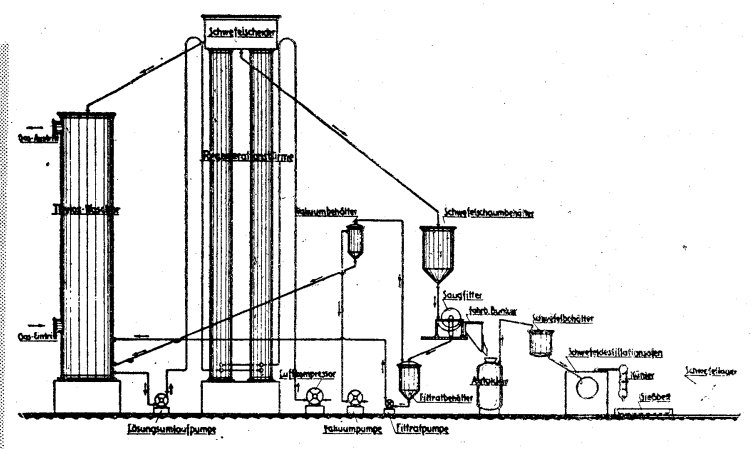

Fig 10. Differentialbeheizung des Koppers-Verbund-Kreisstrom afens

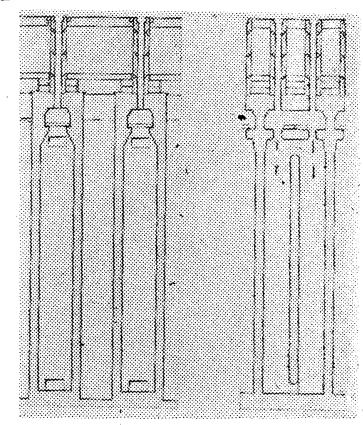

Fig 11. Temperaturverlauf im Gassammelraum von Koksöfen ohne und mit differentialbeheizung

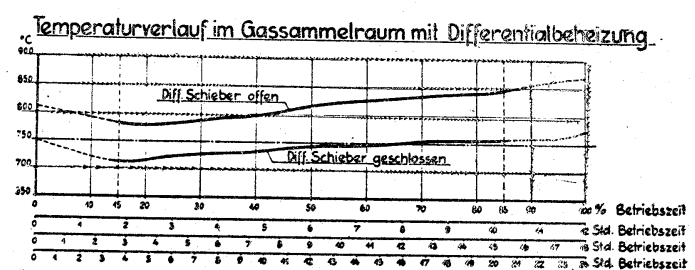

Temperaturverlauf im Gassammelraum ohne Differentialbeheizung

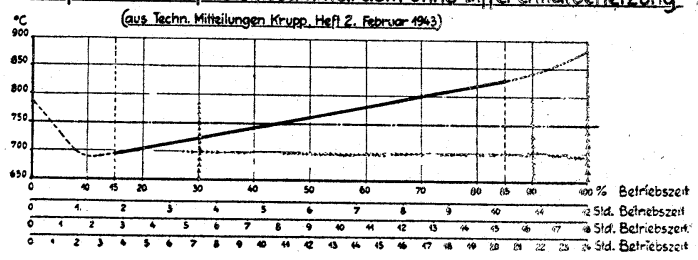

which the oven walls can be heated differently in vertical direction, enabling optional heating of the gas collecting space above the charge to prevent decomposition of valuable by-products. Test showed that the benzene output increased by $10 \%$.

1934 :-Koppers built the first pipe still tar distillation plant for the Rütgers works in Czecko 
Fig 12. Vakuum-Teerestillation Bauart G.f.T.-Koppers

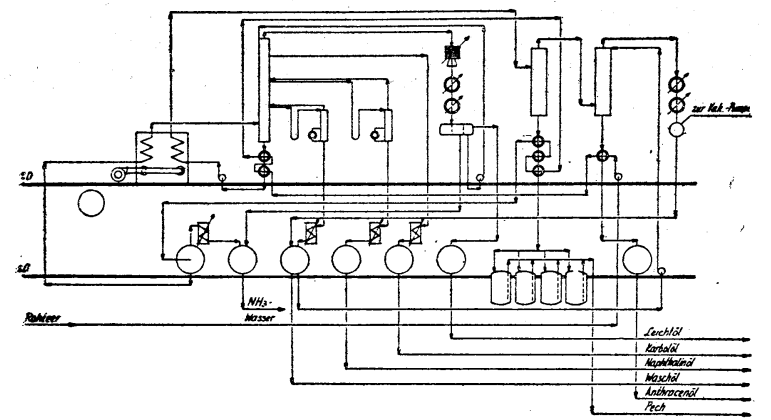

extensions have been ordered. The total production was $2,000,000,000 \mathrm{~m}^{3}$ of synthesis gas.

1937 :- Koppers built his first plant for recovery of $\mathrm{H}_{2} \mathrm{~S}$ from gas under pressure according to the potassium carbonate process. The $\mathrm{H}_{2} \mathrm{~S}$ can be distilled off the solution for recovery of sulphuric acid or sulphur.

This process is now built for Messrs.

Fig 15. Schema des Koppers-PottascheVerfahrens zur Schwefelwasserstoffentfemung aus Femgas
Slowakia, and 1935 the first pipe still plant for benzene recovery from wash oil.

1935:-Koppers built on his own risk a plant for recovery of great quanties of synthesis gas from lignite briquetts for a F. T. -benzene synthesis plant. After proving its success this plant was paid and six

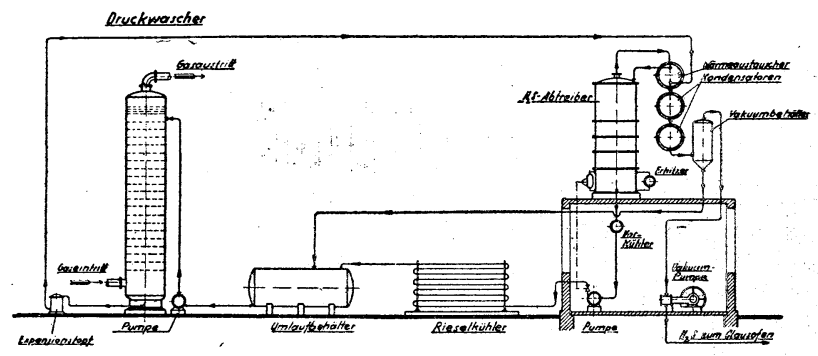

Fig 13. Schemotische Dorstellung der Brikett-Spülgasvergasung.
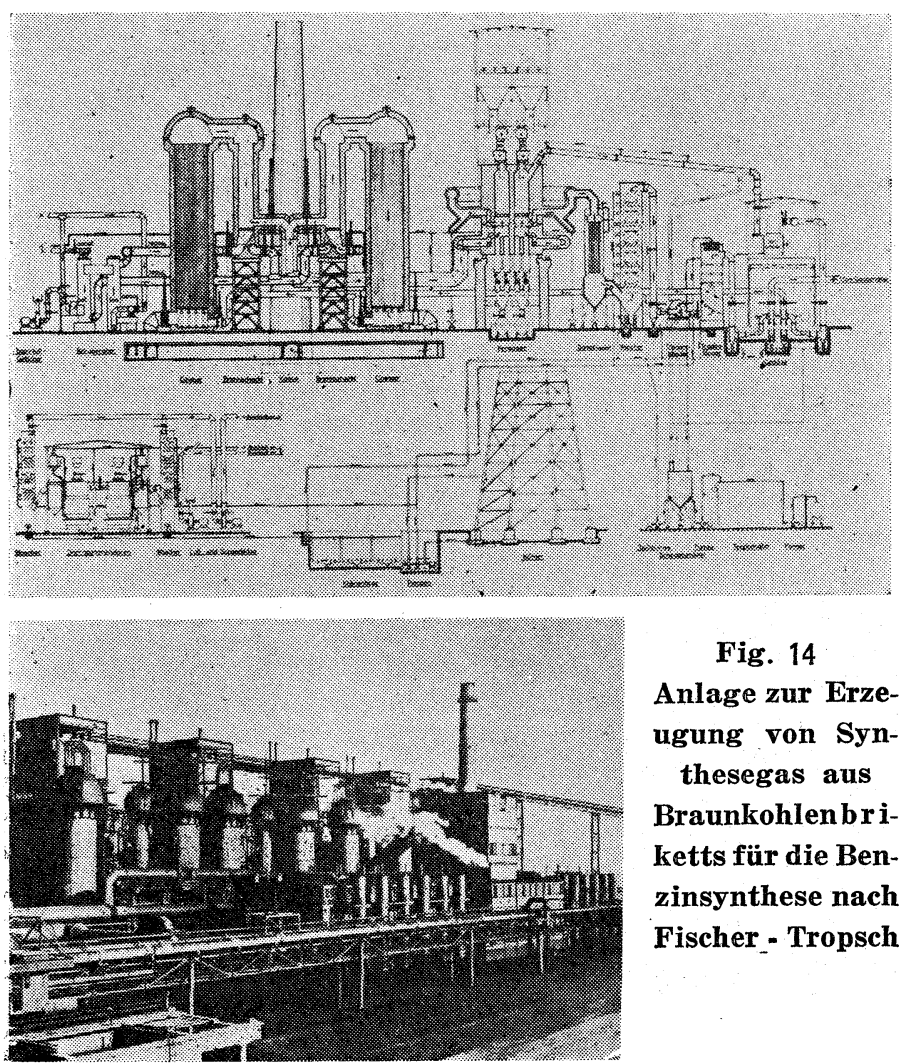

Tokyo Gas Co., Toyosu Works, however, instead of potassium soda will be used.

1938:-Koppers built the first pitch coke ovens in Germany with narrow chamber like coke ovens. Such plants have also been built in Japan during the last war. Pitch coke can replace petrol coke in countries being short of mineral oil, and is an excellent product for manufacture of electrodes due to its low content of ash, sulphur and volatile matters.

1938:-Koppers built also his first plant for reforming of the methane and hydrogen in the coke oven gas into $\mathrm{H}_{2} \& \mathrm{OO}$ for reco very of synthesis gas.

Fig. 14

Anlage zur Erzeugung von Syn-

thesegas aus

Braunkohlen bri-

ketts für die Benzinsynthese nach Fischer - Tropsch
Several of these plants have been also built in Japan and are in operation until now.

1938:-The first test plant was erected by Koppers in Germany for complete gasfication of pulverized solid fuels as coal, coke, lignite, and peat by means of oxygen and steam according to the Koppers-Totzek process, to recover synthesis gas for all 
Fig 16. Thermische Gasumformanlage für Kohlenwasserstoffhaltige Gase

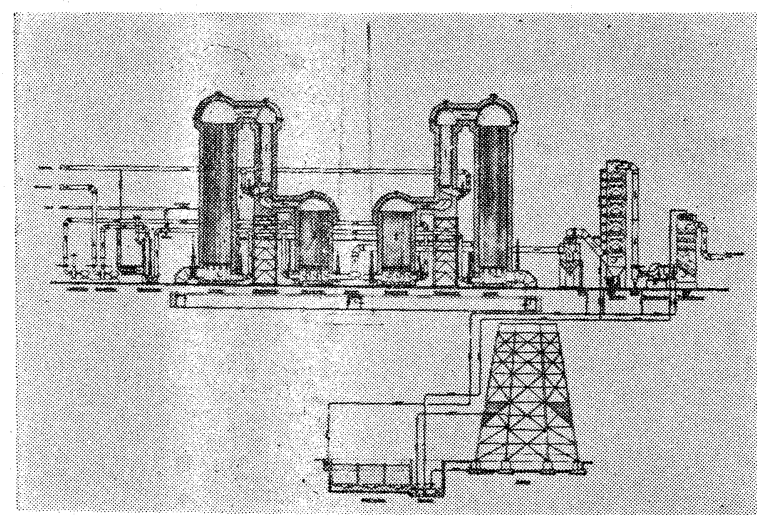

purposes, and many tests have been made.

1941:-Koppers built the first plant for separation of tar and ammonia liquor under pressure, of coke oven plants, attaining a better separation with smaller apparatus.

1947 :-In Louisiana U. S. A. a pilot plant for complete gasification of 50 tons/d of bituminous coal has been built by the Koppers Co. Inc., Pittsburgh according to Koppers Germany process and design. This plant was successfully operated under supervision of Koppers engineers from Germany about one year.

\section{Fig 20. Kohlenstaubvergasung nach Koppers-Totzek}

Fig 17. Versuchsanlage zur Kohlenstaubvergasung nach KoppersTotzek auf dem Steinkohlenberawerk Rheinpreußen-1942

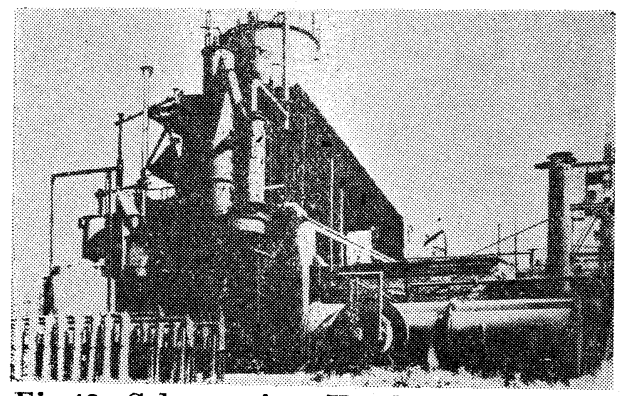

Fig 18. Schema einer Kondensatspül-und Scheideanlage

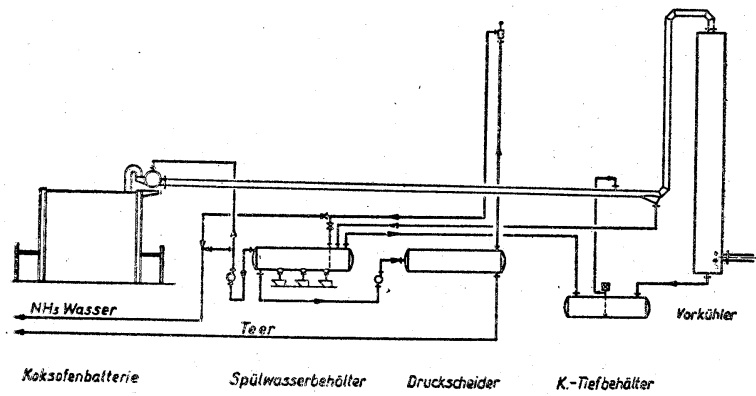

Fig 19. Gasentschwefelung Mittels Ammoniak

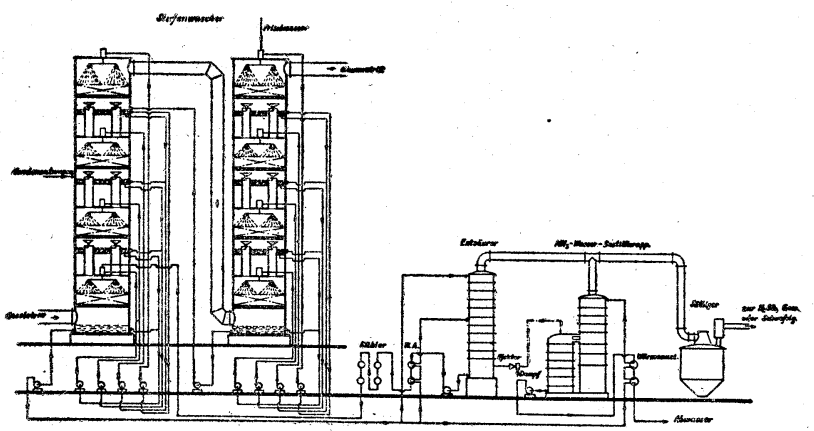

1949 :-Koppers built a great plant for desulphurization of coke oven gas by the ammonia liquor process, and to recover pure block sulphur from the washed out sulphuretted hydrogen.

1949:- The first order was placed with Koppers on a plant on industrial scale for complete gasification of 50 to 100 tons of bituminous coal/day to recover synthesis gas for several purposes in France according to the Koppers-Totzek process.

1950:-The second order was placed

Fig 21. Stickstoffwerk der Typpi Oy in Oulu (Finnland) mit Synthesegaserzeugung durch Steinkohlenstaubvergasung

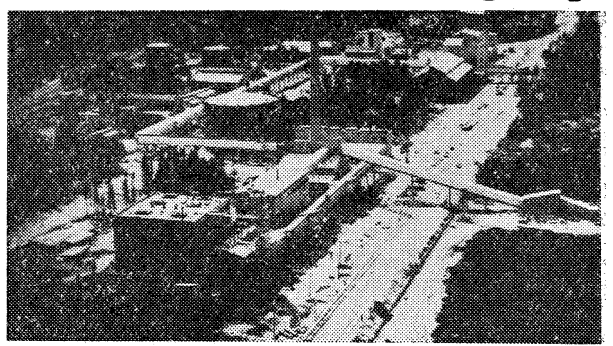


with Koppers on a plant for complete gasification of coal, or lignite, or peat, or oil to recover synthesis gas, for recovery of 60 tons/day of $\mathrm{NH}_{3}$. This plant started operation in July 1952 gasifying about 80 tons of Polish coal first, and since spring time of 1955 about 56 tons of bunker-C- oil without any trouble or interuption.

The produced water gas is of excelent quality for the ammonia synthesis containing $85 \%$ of $\mathrm{CO}+\mathrm{H}_{2}$ when using coal, and $88 \%$ of $\mathrm{CO}+\mathrm{H}_{2}$ when using oil. The methane content is below $0.1 \%$. Due to the excellent quality of the gas, the $\mathrm{NH}_{3}$-production increased by $10 \%$ as only $2110 \mathrm{Nm}^{3}$ of gas were required for 1 ton of $\mathrm{NH}_{3}$. The plant has been built for Messrs. Typpi Oy, Helsinki Finiand at their works in Oulu. The extension of this plant to double its capacity is at present under erection.

Fig 22. Schematische Darstellung einer Perox-Gasentschwefelungs-Anlage

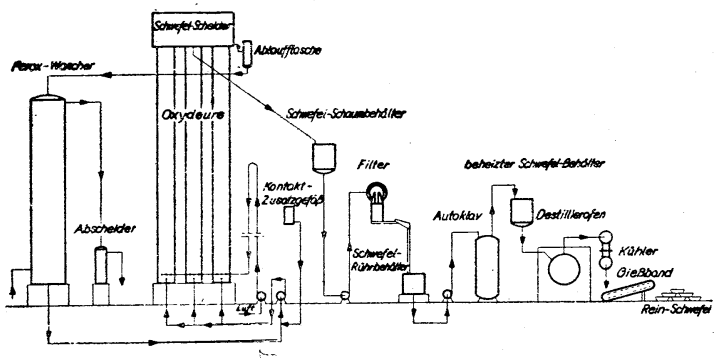

1951:-Koppers built the first catalytic Perox plant for desulphurization of gas on industrial scale. This process is similar to the Thyloxprocess but, uses instead of an arsenate solution a catalyst and enables to recover pure sulphur without traces of arsen. For this, process, however, a cooling water of $20^{\circ} \mathrm{C}$ is condition, what is a draw back for introducing this process in Japan.

1953 :-Koppers built a plant for redistillation and fractionationg of 15,000 tons per month of pressure refined crude benzene of wihich are recovered :

$3 \%$ of a preliminary fraction

$66 \%$ fo pure benzene of $5.4^{\circ} \mathrm{C}$ melting point, which is theoretically $5.5 \%$

$15 \%$ of pure toluene

$7 \%$ of pure xylene

$5 \%$ of Arsol I

$3 \%$ of Arsol II

$1 \%$ of residue.

1954 :-The first order from Japan was placed with Koppers on a plant for recovery of 250,000 $\mathrm{Nm}^{3} / d$ of synthesis gas for ammonia production from minor Joban coal with ash content up to 38
$\%$. The plant ordered by Messrs. Nihon Suiso was heated up September 1, 1955 and is now in operation. Operating figures will be published later after the guaranty test has been made.

1954 :-First erection of a plant for raffination of 500 tons/month of crude benzene under high pressure by hydrogenation with coke oven gas for the gas works Stuttgart according to the patented process of the Badische Anilin and Soda Fabrik. This plant got some improvements vis a vis the big plant of 15,000 tons/month capacity built by the Scholven Chemie A. G. before, and the latter was somewhate modified according to the improvements made by Koppers in Stuttgart. Koppers received meanwhile 3 further orders on such plants of a capacity of 6,000 tons, 1,000 tons and 1,000 tons respectively in France and Germany.

Dr. Schmalenbach reported already in his lecture in 1953 regarding this process.

1955 :-Koppers received from Messrs. Tokyo Gas Co., for their new Toyosu gas work the order on a plant for purification of $2,000,000 \mathrm{~m}^{3} / \mathrm{d}$ of mixed coke oven gas, water gas and producer gas according to the Koppers pressure gas purification process for supply of gas to far distance.

The gas freed of tar and ammonia under low pressure is compressed to $8-10 \mathrm{~kg} / \mathrm{cm}^{2}$ and under this pressure purified from NO, naphthalene, the whole benzene $\mathrm{H}_{2} \mathrm{~S}$ and moisture so that it can be supplied to a far distance without plucking the pipes. Numerous simlar plants have been built already by Koppers in the Ruhr district for supply of coke oven gas to the Ruhrgas netting.

1955 :-Koppers erects a plant for thermical production of town gas from oil at the gas work Düsseldorf. This gas will have the same spec. weight as coke oven gas and also about the same analysis. The plant is intended to cover the peak loads of gas supply, and will start operation in April 1956.

1955 :-Koppers erects a test plant for recovery of a gas from oil containing about $35 \%$ of ethylene for ethylene recovery.

1955 :- Koppers erects a test plant for recovery of town gas from pulverized coal under high pressure.

Results and details of the last three plants can not be given until the plants are tested and the patents are granted.

This enumeration shows only a part of the share of Koppers in promoting the coke oven and gas industry. As I mentioned in the beginning the development of the coke oven system 
seems to be finished, and only some improvements of coke oven armatures may here be mentioned.

\section{Fig 23. Selbstdichtende Koksofentür Bauart Koppers}

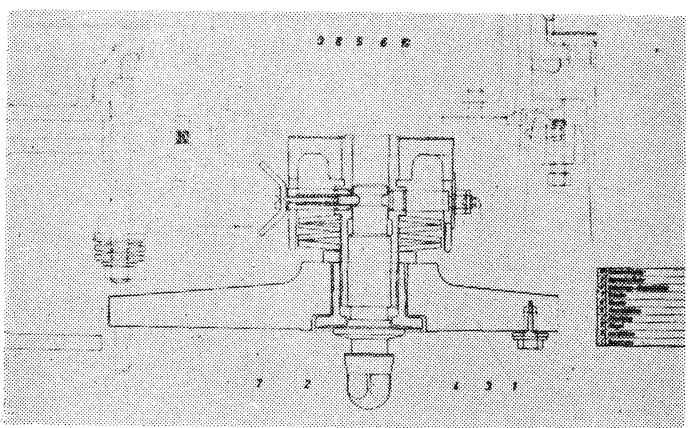

Fig 24. Pneumatische Türbedienung

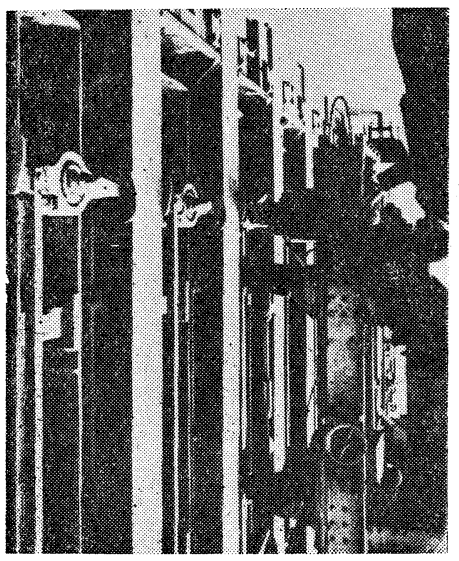

With the increasing height of the chambers from 2.0 to $4.5 \mathrm{~m}$ the sealing of the doors became a problem. The clay luting of the doors was first replaced by asbestos gasket sealings and finaliy by sealing iron on iron, of which the two bolts for tightening the door have been adjusted with spanners of different length giving by different leverage unequal pressure at the upper and lower bolts. Koppers used first small eiectro-motors for bolting the doors, and inserted plate sprigs between door and bolt bars assuring equal pressure of about 5.0 tons on both bolts. Later pneumatic door operation has been developed proving very successfully in practice. The whole process of debolting, lifting and redrawing of the doors and vice versa is now made entirely pneumatically and mechanically eliminating the human element, accelerating the operation, and preventing of damages by too extreme sealing.
For top charge operation Koppers developed a special coal charging cai for unifo$\mathrm{rm}$ and loose distributing the coal in the chamber a prerequisite for uniform carbonization of the charge. A description is given in the pamphlets laid out here.

A very important part of high duty regenerative coke ovens is the reversing winch, which has to reverse the heating about every half hour without failure and in such a way that waste of heating gas and explosions within the oven system are entirely avoided.

Fig 26.

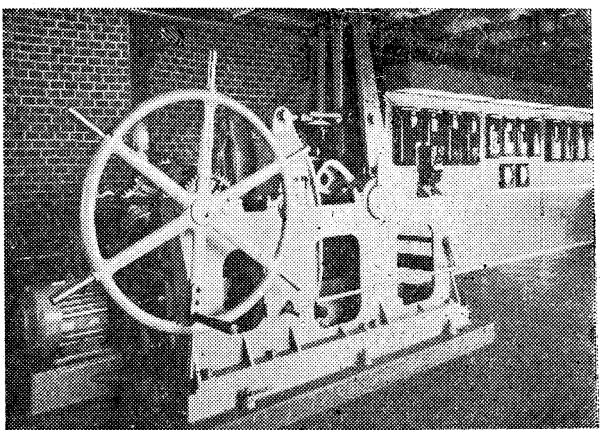

The electricaily operatec and push button started reversing winch of Koppers takes over all necessary proceedings automatically, and can also be operated by hand in case of failure of the electric current.

Any breakage of the towing chains or rods connecting the reversing armatures with the winch would be dangerous to the ovens. A patented inventions of Koppers takes care that in case of such a breakage the levers of the armatures are automatically blocked until the gas admission coks are closed.

An alarm system which is started by a contaci at the pressure indicator warns the operator by a siren to shut at once the gas admission coks by means of the winch, in case the gas pressure in the gas supply main sinks down to a certain 
Fig 27

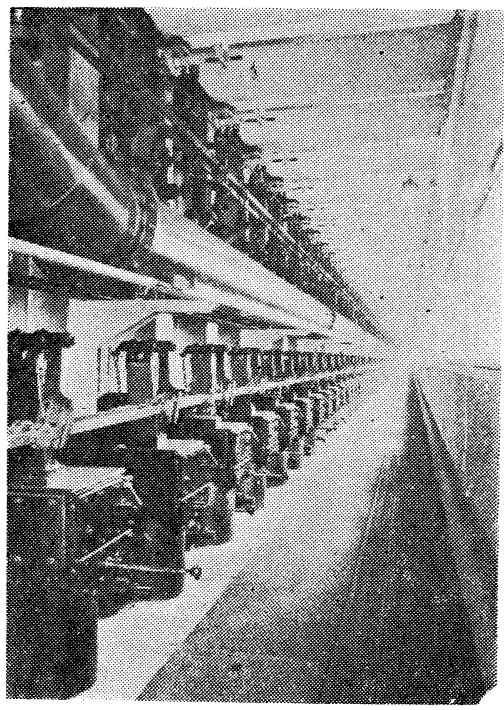

point where air could enter the gas distributing mains and re-ignition could take place and cause an explosion of the gas main.
Within the last year in Germany, England and U. S. A. tests have been made on industrial

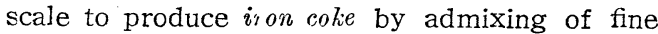
iron ore or flue dust from blast furnaces to high volatile coal. According to reports the tests were successful, and the mixture of coal and iron ore did not affect the coke oven walls when carbonized. The iron coke was firm and of high combustibility; it could be used in the Thyssen liquid slack gas producer in mixture with 40 to $50 \%$ of lump size iron ore and flux. The pig iron recovered had the same properties as commercial pig iron and could be charged into open hearths. Besides the pig iron a lean gas of about $1125 \mathrm{kcal} / \mathrm{m}^{3}$ could be recovered from the producer for heating of the coke ovens.

As Japan has abundant quantities of high volatile coals and a shortage of good caking coal and as fine iron ore is cheaper than lump size one, this process may be of interest also for Japan.

Time is up and I beg to thank the honorable assembly for giving kind audience to my lecture.

\section{会費払込み御願い}

昭和31年度会費御払込みを願いすす

特別会員 年額 1 口 金5,000円

正会員”金 700 円

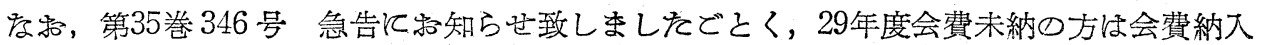

あるまで一時送本を停止致しておりますが，未だ末納の方は至急御払込み下さいますよう

お願い致します。

をお，昭和30年度会費未納の方も早急御払込み下さん。

御送金の場合は（第34巻，343号）振替用紙を御利用下さん。

社団法人 燃料協会

